The observed qualitative difference between fenfluramine and older slimming drugs known to cause dependence therefore serves somewhat to strengthen the belief that fenfluramine will prove not to induce dependence.

\section{Summary}

Slimming pills are often pep-pills. Electrophysiological recordings of nocturnal sleep showed that diethylpropion caused (1) frequent awakenings, (2) suppression of paradoxical (R.E.M.) sleep, and (3) frequent shifts into and increased time in stage 1 sleep (drowsiness). Fenfluramine caused neither (1) nor (2) but caused frequent shifts into and increased time in stage 1 sleep at the expense of stages 3 and 4 . Since fenfluramine caused no delay in the appearance of paradoxical sleep, no suppression, and no hint of withdrawal rebound, it would appear to be qualitatively different from diethylpropion.

All the abnormalities caused by the drugs must be regarded as adverse, but on these grounds fenfluramine would be preferred to diethylpropion. Furthermore, fenfluramine does not share effects on sleep of other drugs which commonly induce dependence.

We thank Mr. N. Stenhouse for the statistical analyses; Dr. R. M. Ellison, Superintendent of Heathcote Hospital, for facilities and his co-operation; and, of course, our subjects. We are indebted to Drug Houses of Australia Ltd. for the special tablets and other assistance.

\section{REFERENCES}

Baekeland, F. (1966). Psychopharmacologia (Berl.'), 10, 179.

Barten, H. H. (1965). Amer. 7. Psychiat., 121, 1210

Berger, R. J., and Oswald, I. (1962). J. ment. Sci., 108, 457.
Caplan, J. (1963). Canad. med. Ass. 7., 88, 943.

Clein, L. J., and Benady, D. R. (1962). Brit. med. 7., 2, 456

Dement, W. (1960). Science, 131, 1705.

Dement, W., and Greenberg, S. (1966). Electroenceph. clin. Neurophysiol., 20, 523.

Dement, W., and Kleitman, N. (1957). Electroenceph. clin. Neurophysiol. 9,073 .

Dewson, J. H., Demen

Science, 156, 403.

C. Wagener, T. B., and Nobel, K. (1967).

Foulkes, W. D. (1962). 7. abnorm. soc. Psychol., 65, 14.

Greenberg, R., and Pearlman, C. (1967). Amer. F. Psychiat., 124, 133. $140,1226$.

Gross, M. M., et al. (1966). \%. nerv. ment. Dis., 142, 493.

Guile, L. A." (1963). Med. F. Aust., 2, 56.

Hill, R. C. and Turner, P. (1967) 7 . Pharm. Pharmacol., 19, 337. Jones, H. S. (1968). Med. \%. Aust., 1, 267.

Jonsson, C. O., Sjöberg, L., and Vallbo, S. (1965). Scand. F. Psychol., 6, 52 .

Jouvet, M. (1965). In Sleep Mechanisms, edited by K. Akert, G. Bally, and J. $P_{j}$. Schadé. Amsterdam.

Kalant, O. J. (1966). The Amphetamines: Toxicity and Addiction. Toronto.

Kuenssberg, E. V. (1962). Brit. med. 7., 2, 729.

Kuenssberg, E. V. (1963). Brit. med. ł., 2, 1406.

Le Gassicke, J., Ashcroft, G. W., Eccleston, D., Evans, J. I., Oswald, I., and Ritson, E. B. (1965). Brit. Y. Psychiat., 111, 357.

Munro, J. F., Seaton, D. A., and Duncan, L. J. P. (1966). Brit. med. 7., 2,624 .

Oswald, I. (1966). Sleep. Harmondsworth, Middlesex.

Oswald, I., Berger, R. J., Jaramillo, R. A., Keddie, K. M. G., Olley, P. C. and Plunkett, G. B. (1963). Brit. F. Psychiat., 109, 66.

Oswald, I., and Priest, R. G. (1965). Brit. med. F., 2, 1093

Oswald, I., and Thacore, V. R (1963). Brit. med. $72,242$.

Rechtschaffen, A., and Maron, L. (1964). Electroenceph. clin. Neurophysiol., 16, 438 .

Roebuck, B. E. (1963). Brit. med. 7., 2, 936.

Seaton, D. A., Duncan, L. J. P., Rose, K., and Scott, A. M. (1961) Brit. med. Y., 1, 1009.

Spence, A. W., and Medvei, V. C. (1966). Brit. F. clin. Pract., 20, 643.

Spence, A. Times, 1967 a 18 July,

The Times, 1967 (18 July, p. 2.

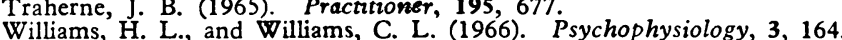

Williams, R. L., Agnew. H. W., and Webb, W. B. (1964). Electroenceph. clins, R. L., Agnew, H. W,

Yules, R. B., Freedman, D. X., and Chandler, K. A. (1966). Electroenceph. clin. Neurophysiol., 20, 109.

\title{
Studies on Iron Absorption in Acute Liver Disease
}

\author{
HELEN BROWN, ${ }^{*}$ B.SC. ; SHEILA T. CALLENDER,* M.D., F.R.C.P. ; J. S. MALPAS, ${ }^{*} \dagger$ M.B., B.SC., M.R.C.P.
}

\section{Brit. med. F., 1968, 1, 799-801}

Patients with cirrhosis of the liver may have an increased absorption of oral iron, and in some of such cases a pancreatic extract will reduce the absorption towards normal (Callender and Malpas, 1963). These findings suggest that associated chronic pancreatic damage is an important element in the altered iron absorption in chronic liver disease, but the part played by liver damage per se is not clear. The present paper reports studies of iron absorption in patients suffering from acute hepatitis and in rats with experimental liver damage.

\section{Animal Studies}

Twenty female Wistar-strain rats weighing 170 to $200 \mathrm{~g}$. were taken at random from a batch of animals maintained since weaning on an iron-supplemented diet (Diet C, McCall et al., 1962). Ten remained on the diet as controls and 10 took the same diet with the addition of $0.1 \% \alpha$-naphthyl isothiocyanate, the approximate daily intake of which was $10 \mathrm{mg}$.

Twelve days later those on the $\alpha$-naphthyl isothiocyanate diet showed yellowness of ears, muzzle, and feet, and had lost an average of $20 \mathrm{~g}$. in weight as compared with an average gain of $17 \mathrm{~g}$. in the controls. All 20 were dosed with $1 \mathrm{ml}$.

\footnotetext{
* Nuffield Department of Clinical Medicine, Radcliffe Infirmary, Oxford.
} t Present address St. Bartholomew's Hospital, London E.C.1.

of a solution containing $250 \mu \mathrm{g}$. of ${ }^{59} \mathrm{Fe}$-labelled ferrous iron per $\mathrm{ml}$. Total body radioactivity was measured after dosing and then one week later. The diet containing $\alpha$-naphthyl isothiocyanate was fed throughout the experiment.

The results of the tests of iron absorption are shown in the Chart. The values for iron absorption in the two groups occupy the same range and have a mean absorption for

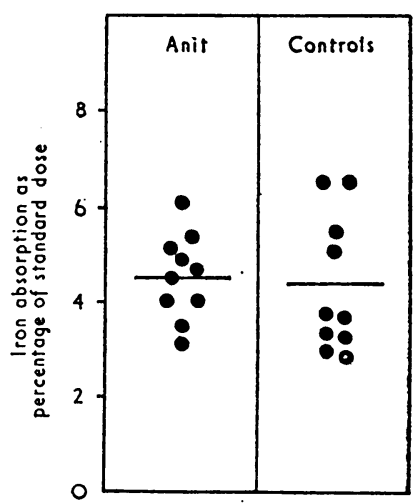

Iron absorption in rats with experimental cirrhosis of the liver caused by $\alpha$-naphthyl isothiocyan ate (anit.) and in controls. $\alpha$-naphthyl isothiocvanate treated rats of $4.5 \%$ and for control rats of $4.4 \%$.

After the test of iron absorption two rats from each group were killed and examined. Micro-haematocrit examinations were done on samples of venous blood, and specimens of liver were taken for histological examination. The plasma of the treated rats was jaundiced, and these rats had lower haematocrits $(33 \%$ and $33 \%)$ than their controls $(41 \%$ and $46 \%)$. The general appearance of the liver in the treated rats was coarser 
TABLE I.-Absorption and Utilization of ${ }^{80} \mathrm{Fe}$ Given as ${ }^{\circ \mathrm{PeSO}}$ or Labelled Haemoglobin in Patients with Acute Liver Disease (For comparison : Mean absorption of ${ }^{\circ 0} \mathrm{FeSO} 6$ : Normals 30\%; Iron-deficient $55 \%$. Mean absorption of ${ }^{80} \mathrm{FeHb}$ : Normals $11 \%$; Iron-deficient $20 \%$ )

\begin{tabular}{|c|c|c|c|c|c|c|c|c|c|c|c|}
\hline $\begin{array}{l}\text { Case } \\
\text { No. }\end{array}$ & Sex and Age & Diagnosis & $\underset{(\mathrm{g} . / 100 \mathrm{ml} .)}{\mathbf{H b}}$ & $\begin{array}{c}\text { Serum Fe } \\
(\mu \mathrm{g} .1 \\
100 \mathrm{ml} .)\end{array}$ & $\begin{array}{l}\text { Bilirubin } \\
\text { (mg./ } \\
100 \mathrm{ml} \text {.) }\end{array}$ & $\begin{array}{l}\text { Alkaline } \\
\text { Pbosph. } \\
\text { K.A. units }\end{array}$ & $\begin{array}{l}\text { Albumin } \\
(\mathrm{g} . / \\
100 \mathrm{ml} .)\end{array}$ & $\begin{array}{l}\text { Alanine } \\
\text { Trans. } \\
\text { S.G.P.T. } \\
\text { units }\end{array}$ & $\begin{array}{l}\text { Faecal Fat } \\
(\mathbf{g} . / 24 \mathrm{hr} .)\end{array}$ & $\begin{array}{c}\text { Percentage } \\
\text { Absorption } \\
\text { of Oral } \\
\text { Iron }\end{array}$ & $\begin{array}{l}\text { Percentage } \\
\text { of Iron in } \\
\text { Red Cells }\end{array}$ \\
\hline 1 & F 29 & $\begin{array}{l}\text { Infectious hepatitis } \\
\text { ? Chlorpromazine } \\
\text { Improving on steroids }\end{array}$ & $12 \cdot 5$ & $\begin{array}{l}472 \\
128\end{array}$ & $\begin{array}{r}19.5 \\
0.9\end{array}$ & $\begin{array}{l}28 \\
29\end{array}$ & $2 \cdot 9$ & $\begin{array}{l}22 \\
82\end{array}$ & $\begin{array}{r}47 \cdot 6 \\
5 \cdot 3\end{array}$ & $\begin{array}{l}\text { Inorgan } \\
15 \cdot 7 \\
13 \cdot 0\end{array}$ & $\begin{array}{r}\mathbf{8} \\
8 \\
2\end{array}$ \\
\hline 2 & M 33 & $\begin{array}{l}\text { Post-gastrectomy } \\
\text { anaemia } \\
\text { Infoctious hepatitis }\end{array}$ & 9 & $\begin{array}{r}21 \\
107\end{array}$ & 2.5 & 48 & 3.5 & 100 & & 58 & 49 \\
\hline 3 & $M 36\{$ & $\begin{array}{l}\text { Infectious hepatitis } \\
\text { Recovered }\end{array}$ & $14 \cdot 4$ & $\begin{array}{l}172 \\
128\end{array}$ & $\begin{array}{l}1.8 \\
0.7\end{array}$ & $\begin{array}{r}12 \\
6\end{array}$ & $\begin{array}{l}3.9 \\
5.3\end{array}$ & 460 & $6 \cdot 4$ & $\begin{array}{l}15 \\
32\end{array}$ & $\begin{array}{r}7 \\
19\end{array}$ \\
\hline 4 & $P 63\{$ & $\begin{array}{l}\text { Infectious hepatitis } \\
\text { Improving } \\
\text { Recovered }\end{array}$ & $12 \cdot 3$ & $\begin{array}{l}256 \\
140 \\
100\end{array}$ & $\begin{array}{c}11 \cdot 6 \\
9 \\
2\end{array}$ & $\begin{array}{r}18 \\
13 \\
8\end{array}$ & $\begin{array}{l}3 \cdot 5 \\
4\end{array}$ & $\begin{array}{r}1,500 \\
130 \\
10\end{array}$ & $\begin{array}{l}5.3 \\
1.7 \\
1.0\end{array}$ & $\begin{array}{r}9 \\
20 \\
2\end{array}$ & $\begin{array}{l}0 \\
5 \\
2\end{array}$ \\
\hline 5 & F 35\{ & $\begin{array}{l}\text { Serum hepatitis } \\
\text { Improving on steroids }\end{array}$ & $\begin{array}{l}10.9 \\
11.7\end{array}$ & $\begin{array}{l}200 \\
184\end{array}$ & $\begin{array}{l}3 \cdot 2 \\
2 \cdot 4\end{array}$ & $\begin{array}{l}10^{\circ} \\
10\end{array}$ & $2 \cdot 2$ & $\begin{array}{l}260 \\
106\end{array}$ & $\begin{array}{l}18 \cdot 9 \\
17 \cdot 1\end{array}$ & $\begin{array}{r}5 \\
28\end{array}$ & $\begin{array}{r}0 \\
26\end{array}$ \\
\hline 6 & F 43\{ & $\begin{array}{l}\text { Lupoid hepatitis } \\
\text { Improving on steroids }\end{array}$ & $14 \cdot 9$ & $\begin{array}{r}164 \\
60\end{array}$ & $\begin{array}{l}8 \\
2\end{array}$ & $\begin{array}{l}18 \\
13\end{array}$ & $3 \cdot 2$ & $\begin{array}{r}400 \\
20\end{array}$ & $\begin{array}{r}13 \cdot 6 \\
4 \cdot 8\end{array}$ & $\begin{array}{l}43 \\
29 \\
\text { Haemogl }\end{array}$ & \begin{tabular}{|l}
11 \\
28 \\
obin Iron
\end{tabular} \\
\hline 7 & P 56 & $\begin{array}{l}\text { Recovering. Infectious } \\
\text { hepatitis }\end{array}$ & $14 \cdot 8$ & 52 & 0.3 & 28 & $5 \cdot 1$ & & 3 & 39 & 6 \\
\hline 8 & F 56 & $\begin{array}{l}\text { Lupoid hepatitis on } \\
\text { steroids }\end{array}$ & $13 \cdot 9$ & 120 & 3 & & $2 \cdot 6$ & 160 & $7 \cdot 8$ & 16 & 8 \\
\hline
\end{tabular}

than that in their controls. The livers of control rats showed normal histological appearances; those of the treated rats showed a striking proliferation of the bile ducts, infiltration by lymphocytes and polymorphs, and some haemosiderosis.

\section{Human Studies}

Eight subjects with hepatitis were studied at various stages of their disease (Table I). In one the condition was almost certainly due due to serum hepatitis, and in two lupus erythematosus cells were found ; these two cases were classified as lupoid hepatitis. One subject (Case 1) may have had chlorpromazine jaundice, though the symptoms which antedated her taking chlorpromazine suggested the diagnosis of infectious hepatitis.

Where possible a test of iron absorption was carried out during the acute stages of the illness and again during or after recovery. Iron absorption was calculated from the amount of unabsorbed radioactivity found in the faeces after an oral dose of either ${ }^{59} \mathrm{Fe}$-labelled ferrous sulphate or labelled haemoglobin. The dose was adjusted to contain $5 \mathrm{mg}$. of iron (Callender et al., 1957). A blood sample was taken 10 to 14 days after each dose in order to measure the percentage of the dose utilized for new red cell formation.

The effect on the absorption of iron of giving $2.5 \mathrm{~g}$. of pancreatin in the form of powdered pancreas (Cotazym) was studied in three patients.

A blood count, estimations of serum iron, liver function tests, and faecal fat studies were done as nearly as possible at times corresponding to the various absorption studies. The method of Bothwell and Mallett (1955) was used for estimations of serum iron, and the faecal fat excretion was measured by the method of Van de Kamer et al. (1949).

\section{Results}

As had been noted previously (Peterson, 1952) the serum iron tended to be high during the acute stages of hepatitis and fell as the condition recovered. The only low serum iron at the time of the test was in a woman (Case 7) who was already recovering from her hepatitis. One man (Case 2) had been awaiting admission for investigation of postgastrectomy iron-deficiency anaemia when he developed his hepatitis. The serum iron taken shortly before his admission with jaundice had been $21 \mu \mathrm{g} . / 100 \mathrm{ml}$., but when the test was carried out it had risen to $107 \mu \mathrm{g} . / 100 \mathrm{ml}$., though the mean corpuscular haemoglobin concentration was only $29 \%$.
With inorganic iron four of the six subjects showed a normai or low absorption of iron in the more acute stages of the disease. The absorption either remained the same or increased during recovery. The patient with postgastrectomy irondeficiency anaemia showed a high absorption similar to that in uncomplicated iron deficiency. The patient with lupoid hepatitis also showed a high absorption.

Two subjects were tested with haemoglobin iron. One had a sideropenia though she was not anaemic (serum iron $52 \mu \mathrm{g}$./ $100 \mathrm{ml}$.) and absorbed the dose well. The other had lupoid hepatitis and was on steroids at the time of the test. She also absorbed iron well.

Steatorrhoea (a daily excretion of over $6 \mathrm{~g}$. of fat) was a feature in five subjects, but it was evident that this symptomatic steatorrhoea, unlike idiopathic steatorrhoea, was not correlated with reduced iron absorption. Thus in Case 5 the steatorrhoea was unchanged at the time of her second test though absorption had improved from $5 \%$ to $28 \%$ of the oral dose.

The addition of pancreatin did not affect either inorganic iron or haemoglobin iron absorption in the three subjects in whom it was tested (Table II).

TABLE II.-Absorption of ${ }^{59} \mathrm{Fe}$ Given as ${ }^{59} \mathrm{FeSO}$ or Labelled Haemoglobin to Patients with Acute Liver Disease

\begin{tabular}{c|cc|c}
\hline & \multicolumn{4}{|c}{ Percentage Absorption of Oral Iron } \\
\hline Case No. & Without Pancreatin & With Pancreatin \\
\hline 7 & 39 & Inorganic Iron \\
6 & 43 & Haemoglobin Iron & 43 \\
8 & 16 & & 16 \\
\hline
\end{tabular}

\section{Discussion}

Our results are at variance with those reported by Turnberg (1966). All five of the subjects with acute hepatitis studied by him showed greatly increased iron absorption from a standard meal labelled with ${ }^{59} \mathrm{Fe}$. All five also had high levels of serum iron at the time of presentation, but the values subsequently dropped to subnormal levels (less than $60 \mu \mathrm{g} . / 100 \mathrm{ml}$.), in one case even as low as $11 \mu \mathrm{g} . / 100 \mathrm{ml}$. In the serial studies of serum iron in 60 cases of acute hepatitis reported by Peterson (1952) the serum iron dropped from excessively high levels to normal but not to subnormal levels. It is possible, therefore, that in Turnberg's cases the high absorption was associated with a latent iron deficiency. The two subjects in the present series who showed the highest absorption were undoubtedly iron-deficient. 
The high absorption in lupoid hepatitis is interesting in that R. Williams (personal communication, 1965) has also found a high iron absorption in this condition; that this is not due to accompanying pancreatic damage is suggested by the finding that neither of these two patients showed a diminished iron absorption when the test was repeated with the addition of pancreatin. A third patient with infectious hepatitis also showed no change in absorption with the addition of pancreatin.

The condition produced in rats by $\alpha$-naphthyl isothiocyanate has been described as "experimental cirrhosis." It is a chemical damage characterized by massive proliferation of biliary epithelial cells, which occurs not only to areas recovering from coagulative necrosis of the parenchyma but also independently (Steiner and Carruthers, 1963). It is debatable, of course, whether this can be regarded as comparable to hepatitis of man. Nevertheless, the liver changes which were produced in our test animals did not influence iron absorption. Higginson et al. (1963) also showed no effect on iron absorption in rats in which chronic liver damage had been produced by carbon tetrachloride.

\section{Summary}

Absorption of iron-59 in the form of ferrous sulphate and labelled haemoglobin has been tested in patients having various forms of acute hepatitis. Iron absorption was in the lower range of normal in patients with acute liver disease, except those who had lupoid hepatitis or iron deficiency. Pancreatic extract did not affect the absorption of iron in these patients. Chemical liver damage in rats did not affect iron absorption.

\section{REFERENCES}

Bothwell, T. H., and Mallett, B. J. (1955). Biochem. 7., 59, 599. Callender, S. T., Mallett, B. J., and Smith, M. D. "(1957). Brit. S Haemat., 3, 186

Callender, S. T., and Malpas, J. S. (1963). Brit. med. f., 2, 1516. Higginson, J., Grady, H., and Huntley, C. (1963). Lab. Invest., 12, 1260. MoCall, M. G., Newman, G. F., O'Brien, J. R. P., Valberg, L. S., and Witts, L. J. (1962). Brit. F. Nutr., 16, 297.

Peterson, R. E. (1952). f. Lab. clin. Med., 39, 225

Steiner, J. W., and Carruthers, J. S. (1963). Lab. Invest., 12, 471.

Turnberg, L. A. (1966). Amer. f. dig. Dis., 11, 20.

Van de Kamer, J. H., Huinink, H. ten B., and Weyers, H. A. (1949). biol. Chem., 177, 347 .

\title{
Increased Factor IX Levels in Puerperium during Administration of Diethylstilboestrol
}

\author{
D. G. DANIEL, ${ }^{*}$ M.B., M.R.C.O.G., D.C.H. ; A. L. BLOOM, † M.D., M.C.PATH. ; J. C. GIDDINGS, $\ddagger$ A.I.M.L.T. \\ H. CAMPBELL,§ M.A., M.B., F.S.S. ; A. C. TURNBULL,\| M.D., F.R.C.o.G
}

Brit. med. F., 1968, 1, 801-803

The administration of diethylstilboestrol for the suppression of lactation has been reported to increase the incidence of puerperal thromboembolism (Daniel et al., 1967). Though a relation between increased levels of coagulation factors in blood and thromboembolic disease has not been firmly established in vivo, there is evidence that the activity of factors IX, XI, and XII is essential for the development of thrombus in the ligated veins of experimental animals (Wessler and Reimer, 1960).

The present paper describes the results of a study of factor IX levels in the plasma of puerperal women and reports the new observation that diethylstilboestrol administration causes a highly significant increase in factor IX level.

\section{Method}

All patients investigated had a normal labour and puerperium. There were no thromboembolic episodes. One group was lactating; in the second group lactation was suppressed without the use of oestrogens, diuretics, or changes in fluid intake-" natural suppression"; and in the third group lactation was suppressed by the administration of diethylstilboestrol (10 mg. t.i.d. for three days ; $10 \mathrm{mg}$. b.d. for three days ; and $10 \mathrm{mg}$. daily for three days)-“" stilboestrol suppression." Treatment was begun on the first day of the puerperium, the first dose of diethylstilboestrol being given at 6 a.m. each day.

\footnotetext{
Registrar, Department of Obstetrics and Gynaecology.

Senior Lecturer, Institute of Pathology.

Senior Technician, Institute of Pathology.

Senior Lecturer, Department of Medical Statistics.

Professor of Obstetrics and Gynaecology

Welsh National School of Medicine, Cardiff.
}

At 8 a.m. $4.5 \mathrm{ml}$. of venous blood was obtained without stasis and added to $0.5 \mathrm{ml}$. of $3.8 \%$ sodium citrate. Factor IX was assayed "blind"-that is, without knowledge of the group to which the patient belonged. The technique used was a standard one-stage method similar to that described by Hardisty and Ingram (1964), utilizing a kaolin-activated system consisting of stored $\left(-20^{\circ}\right.$ C.) plasma from a patient with severe factor IX deficiency, adsorbed fresh normal plasma to supply factors VIII and V, and phospholipid. The mean value in non-pregnant adults was $100 \%$, with a normal range of 50 to $150 \%$.

\section{Results}

Altogether 171 estimations were performed in 111 mothers64 in the 43 lactating patients, 79 in the 48 who had "stilboestrol suppression," and 28 in the 20 who had "natural suppression." The mothers who had duplicated assays did not differ significantly from those with a single assay, and it is proposed to analyse all the estimations irrespective of whether or not they were duplicates. The obstetric characteristics of these women were recorded and their mean age, parity, duration of labour, and estimated blood loss are shown in Table I

TABle I.-Mean Age, Parity, and Duration of Labour and Blood Loss of

\begin{tabular}{|c|c|c|c|}
\hline Characteristic & $\begin{array}{c}\text { Lactating } \\
\text { Group }\end{array}$ & $\begin{array}{c}\text { Stilboestrol } \\
\text { Group }\end{array}$ & $\begin{array}{c}\text { Natural } \\
\text { Suppression }\end{array}$ \\
\hline 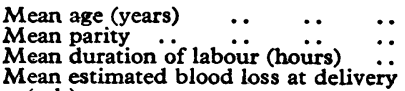 & $\begin{array}{r}27 \cdot 1 \\
1 \cdot 0 \\
9 \cdot 2\end{array}$ & $\begin{array}{r}25 \cdot 1 \\
1 \cdot 3 \\
7 \cdot 0\end{array}$ & $\begin{array}{r}27 \cdot 0 \\
1 \cdot 6 \\
4 \cdot 5\end{array}$ \\
\hline $\begin{array}{lllll}(\mathrm{ml} .) & . . & \ldots & \ldots & \ldots\end{array}$ & 128 & 123 & 150 \\
\hline
\end{tabular}

